\title{
Special Collections of Black Literature in the Traditionally Black College
}

A study of collections of black literature in black colleges and universities, including discussions of eight principal collections in these institutions and one major collection in a public library; the organization, administration, and personnel for such collections; kinds of materials collected; programs and services furnished by them; and financial provisions made for their development.

\begin{abstract}
A WE VIEW IT TODAY, black librarianship, like black education, is between two worlds. The full entrance of black librarianship into the mainstream of librarianship in general is yet to be achieved, and it continues to lie in the outer realm of those institutions which were created to serve a purely segregated society. The high mechanization, massive collections, and generous budgets that characterize many of the prestigious libraries in America are unknown to black libraries. Black institutions and their libraries were born and survived against great odds: those imposed by the society in which these libraries were created, and those imposed as the result of chronic underfinancing.

In his study of the predominantly Negro colleges and universities, Earl J.
\end{abstract}

Mrs. Smith is university librarian, Fisk University, Nashville, Tennessee. This article is based on a chapter of the volume Black Academic Libraries and Research Collections, scheduled for publication by the Scarecrow Press. This project was supported by a grant from the Council on Library Resources.
McGrath concluded that these colleges as a group "lack their share of distinctive or exceptional libraries." 1 This conclusion may be challenged when critical insight is given to the primary and secondary resource materials collected by some of these libraries. Almost immediately, the incompleteness of scholarship is clearly visible as the untapped sources of black studies materials are identified in the black libraries. While, as a whole, these libraries may be indistinctive and unexceptional, elements of some of them are both distinctive and exceptional.

Libraries in the black institutions have been neither self-sufficient nor self-contained. Despite the fact that there are unique elements among them, the development of these libraries and their collections in black studies materials gives evidence of their potential for contributing to the development of scholarship. The depth that these collections have achieved may be directly attributed to the foresight of early librarians, or sometimes faculty persons, who were endowed with the determination, dedication, and interest necessary 
to preserve black history and culture in records.

\section{HistoricAL BACKGROUND}

Patterns in the development of special collections of black literature in the traditionally black colleges vary. In some cases, materials on this subject were in the collection which was established when the college was founded, while in other cases it was through the generosity of benefactors, either in gifts of funds or of materials, that their collections were established. As may be seen in the history of black libraries in general, full histories of the development of these collections are lacking. Through bits and pieces given in some of their records, however, a sketch history can be given.

Special collections of black culture may be found in various types of libraries throughout the United States. One group of these comprises the black institutions-libraries in black colleges and universities, black branches of public libraries, special black research centers, black museums, and black associations and organizations. Other groups include college libraries in the predominantly white institutions; university libraries; private or university-related research libraries; larger public libraries; state libraries; libraries of associations and learned societies (including groups that have religious affiliations); historical societies of states, cities, and counties; museums; and governmental libraries (including the National Archives, presidential libraries, and the $\mathrm{Li}$ brary of Congress).

Libraries in various types of black institutions, whether public or private, academic, political, or social, provide rich and valuable collections of manuscript and archival materials for research in black culture. Unlike the special collections that are found in the predominantly white colleges and universities, special collections that are found in black colleges and universities tend to be limited to subjects on blacks, or subjects that are black-related. For example, it would not be impossible to find in the black institutions papers of an organization or of a leader that related in some way to the black man's struggles.

Throughout the years, libraries in the black colleges have included materials on black subjects in their collections as they were required to meet the needs of curricular programs in black history or black literature. It may be said that black studies have their founding in the curricular programs offered early in the black colleges. Not infrequently these few courses were offered as a requirement for all students. For the most part, materials supporting these courses were added to the general collection. An examination of collections in many of these institutions for the purpose of a survey of libraries and research collections in the traditionally black colleges which this writer conducted revealed that first editions of important works long since out of print were located on the open shelves, attesting to the fact that librarians or faculties in these institutions had an early interest in gathering black materials.

Collection practices also resulted in the purchase of black newspapers and periodicals. The National Survey of Higher Education of Negroes reported in 1942 that

In their holdings of Negro periodicals and newspapers ... the collections of the Negro institutions are more substantial [than their holdings in other newspaper and periodical titles]. Twenty-five colleges were checked for their holdings of 5 Negro periodicals: The Crisis, Journal of Negro Education, Journal of Negro History, Opportunity, and Quarterly Review of Higher Education Among Negroes. With but two exceptions they hold all or all but one of the 5 Negro periodi- 
cals mentioned. These same institutions were asked also to report on their holdings of Negro newspapers. The returns to the questionnaire show that their holdings of Negro newspapers are fairly strong. ${ }^{2}$

Libraries in eight of the traditionally black colleges examined for this survey maintain exceptionally rich resources in black studies. These are Atlanta University, Dillard University, Fisk University, Hampton Institute, Texas Southern University, Lincoln University (Pennsylvania), Tuskegee Institute, and Howard University. While only seven of these libraries participated in the survey, the eighth, Howard University, is being reported because of its significance to the purpose of the survey. Each of the eight libraries was visited in connection with the project, and their collections of black materials were examined in as much detail as possible.

\section{Atlanta University}

At Atlanta University, the history of the Negro collection as a separate department dates back to 1946 , when the university purchased the famous Henry P. Slaughter Collection. Represented in this collection were materials by and about the black man from many countries. In 1932 Anson Phelps presented to the Trevor Arnett Library at Atlanta University a collection of papers of Thomas Clarkson, English abolitionist, who lived between 1760 and 1846 .

The larger Negro Collection also contains a Countee Cullen Memorial Collection of black materials, founded at the university in 1942 by Harold Jackman, a friend of the late Countee Cullen. The founder moved in artistically creative circles in America and in Europe and was associated with the brilliance of the Harlem Renaissance during the 1920s and 1930s. An authority on arts and letters, he was also consistently devoted to the major artistic movements in Harlem and in Greater New York. He met some of the notable par- ticipants of the Harlem Renaissance (a literary and cultural movement among black people, centered in Harlem), such as Langston Hughes, Rose McClendon, Claude McKay, and Countee Cullen. The Harold Jackman Memorial Committee continues the efforts of Jackman by presenting additions to the collection periodically. ${ }^{3}$

The Thayer Lincoln Collection was opened in the Atlanta library in 1953. Items there form perhaps the most important collection on "The Great Emancipator" that is located in the South. The collection was a gift of Mrs. Anna Chrittendon Thayer of New York, who maintained a lifetime interest in Lincoln.

Recent additions to the collections are the papers of Irwin McDuffie, Clark Foreman, the Chocotoquah Circle, and C. Eric Lincoln, who has written on the Black Muslims in America and who served on the Atlanta faculty.

\section{Dillard University}

In 1969, when the Amistad Research Center moved from Fisk to Dillard, it took an unusual collection of research items to a campus where few materials of that nature had been maintained. Although not properly a part of the Dillard library or of the university, it may be counted among the collections on the black campuses. The American Missionary Association Archives, which form the major portion of the collection, were formerly at Fisk University, where they were deposited in 1947.

Other materials in the Amistad Center include the Countee Cullen Collection, the American Home Missionary Society Archives, the Mary McLeod Bethune Papers, the Marguerite D. Cartwright Papers, and Archives of the Race Relations Department of the United Church Board for Homeland Ministries.

\section{Fisk University}

One of the oldest, most exhaustive, 
and most distinguished collections of black studies materials is housed in the Fisk University library. The history of the institution indicates that, when it was founded in 1866 , there were some materials about the black man in the library which was already established at that time. When a new building was erected in 1908 to serve as a library and for other purposes, provisions were made in it to house special black materials.

Fisk made its first systematic effort to assemble materials by and about the black people in 1929-30, when it made special provision for housing these items in a separate collection as a part of the library's resources. Foreign dealers were consulted in an effort to obtain materials. Some of the outstanding purchases of the day included manuscripts which dealt with the early history of the black domestic servant in Europe.

Arthur A. Schomburg, a Puerto Rican of African descent, was appointed curator of the collection in 1929. Later associated with the Schomburg Collection of the New York Public Library as curator, Schomburg provided the impetus for maintaining a collection which was similar to his own distinguished one.

In 1936 the Fisk library received its first big boost, both in financial support and in materials acquired. In that year Fisk purchased the entire library of the Southern YMCA College located in Nashville, Tennessee. The YMCA College library existed under the direction of W. D. Weatherford, who was a local pioneer in collecting materials in the field of race problems. The YMCA library specialized in securing materials relating to the black man since 1865 . As the YMCA collection merged with the Fisk collection, which specialized in black materials prior to 1865 , an outstanding group of research materials was formed.

The Fisk collection has been greatly augmented by periodic gifts and purchases. The E. R. Alexander Collection, founded at Fisk in 1945, is an example of this. Established by Mrs. Alexander in honor of her husband, the intention was to provide for Fisk the opportunity of acquiring items that might be too costly for the university to purchase otherwise. Of particular importance among the materials there were the more than 200 published minstrel sketches.

A small, yet valuable, group of manuscripts, photographs, programs, sheet music, and other items was presented to Fisk in 1948, forming the Scott Joplin Collection. The Langston Hughes Collection, presented to Fisk in the 1940s by the author himself, also helped to enrich the history and resources of the library. Upon the author's death in 1967, and under terms specified in his will, a large collection of tape and disc recordings was added to the existing Langston Hughes Collection.

The Charles Waddell Chesnutt Collection, acquired by Fisk in 1952, includes important research materials relating to this popular figure.

In 1962 Mrs. Jean Toomer presented to the Fisk library the papers of her husband, one of the most significant writers of the Harlem Renaissance. An additional group of papers was added in 1967, after the death of Jean Toomer.

Among other groups of materials which the Fisk library acquired were the papers of Charles Spurgeon Johnson in 1967, the Julius Rosenwald Fund Archives in 1948, and a considerable number of items of W. E. B. DuBois in 1961.

Although not dealing exclusively with black subjects, the George Gershwin Memorial Collection of Music and Musical Literature is a valuable source of materials relating to the black man. The collection was presented to Fisk in 1944 by 
Carl Van Vechten, in honor of his close friend.

An unusual part of the Fisk collection is a group of paintings which form the Baldridge Collection. These sketches were presented to the library in 1931 by Samuel Insull of Chicago.

More recent additions to the Fisk collection include a group of 1,334 notable titles on the black man in Africa and America, the Goodman-Schwerner-Cheney Collection of black books for children, and smaller manuscript collections such as those of Naomi Long Madgett, Slater King, John W. Work, Louise Meriwether, William Lloyd Imes, and Robert Burgette Johnson, son of Charles Spurgeon Johnson.

\section{Hampton Institute}

The Hampton collection was established in 1905, when George Foster Peabody purchased 1,400 books, pamphlets, and other documents from Tucker A. Malone and loaned them to the library. The loan was changed to a gift in 1908 .

In 1914 the private collection of Phil B. Brooks of Washington, D.C., was purchased. This collection of 10,000 books, pamphlets, and documents dealt with slavery and reconstruction in the United States. Included were original bills of slaves and inventories of slaves on plantations.

Among the archival materials in the collection, some of which date back to 1868 , are items on the proceedings of the Lake Mohonk Negro Conference; slavery documents; records and correspondence relating to the American Missionary Association and Hampton Negro Conference; 3,000 photographs of persons and events in the history of the institute; and papers relating to Hollis Burke Frissell, Samuel C. Armstrong, Booker T. Washington, Alexander Crummell, Frederick Douglass, James Weldon Johnson, and Mary McLeod Bethune. Other items in the col- lection include transcripts of interviews with former slaves in Virginia.

Hampton's early emphasis on education for black as well as Indian students is represented in the archives. Letters to Indians and materials on the Indian Rights Association are included.

Beginning in 1970, rigorous efforts were made to expand and to update substantially the collection of black titles. The Hampton collection is perhaps the foremost untapped source for research in black studies. Unlike libraries at Howard, Fisk, and Tuskegee, the Hampton collection has been overlooked by scholars who write on black subjects.

\section{Howard University}

In 1914 the Moorland Foundation, the Library of Negro Life and History, was established by the board of trustees of Howard University. At that time one of the trustees, Jesse E. Moorland, gave the university his private library of more than 3,000 items relating to black subjects, many of which were engravings, portraits, manuscripts, curios, pictures, and clippings. Through a combination of the Moorland materials and those of Lewis Tappan, which had been donated to the library in 1873 , one of the most valuable collections on antislavery literature was formed.

Through the years numerous collections have gravitated to the Moorland Foundation and have thus made possible a constantly growing collection of great significance.

The Moorland Foundation is not unlike the notable black collections assembled in such black institutions as Hampton, Tuskegee, and Fisk in the manner in which it developed during the years. Although the Moorland Foundation was built around two private libraries, the distinguishing feature of its development has been in its relationship to the curriculum. Its focus and expansion were basically conditioned by courses which Howard offered in black life and 
culture as well as by its traditional courses which also included a study of black subjects.

At the time of this investigation, the collection contained over 100,000 cataloged and indexed volumes. Some of the manuscript materials in the collection include papers of Blanche Kelso Bruce, Thomas Clarkson, Frederick Douglass, E. Franklin Frazier, the Grimke family, Oliver Otis Howard, Alain Leroy Locke, Kelly Miller, the Washington, D.C., branch of the NAACP, P. B. S. Pinchback, Rosey Pool, Joel E. Spingarn, Arthur E. Spingarn, Mary Church Terrell, U.S. Colored Troops, Booker T. Washington, and Daniel Hale Williams.

\section{Texas Southern University}

The Heartman Negro Collection of Texas Southern University was purchased in 1948 from Charles Frederick Heartman, a book dealer and author, who spent from forty to fifty years gathering the materials for his private collection. Most of the collection was developed near Biloxi, Mississippi. For many years the Heartman Collection had a historical emphasis, while in recent years the entire emphasis of the collection of black literature has centered on more contemporary items.

The private collection of another individual, whose identity has not been determined, also helped form the basis for the development of the black collection at Texas Southern. Together these two collections helped form perhaps the largest and most important collection of this type in the southwestern part of the United States. The library also houses the university's archives, which date from the founding of Texas Southern in 1947.

\section{Lincoln University}

While the exact origin of the Negro Collection at Lincoln University (Pennsylvania) is unknown, the collection was established between 1935 and 1940 . Holdings include over 6,000 volumes, numerous periodicals, pamphlets, and other items. Books on Africa, which are included, emphasize the area south of the Sahara.

University archives, dating back to 1845 , have been collected. In addition, the library contains the minutes of the Pennsylvania Colonization Society, covering the period 1838-1913. Of particular importance is the Langston Hughes Collection, which contains the personal library and certain literary effects of this noted Harlem Renaissance writer.

Special gifts which the library has received in recent years include the Langston Hughes Collection of 3,000 items; the Reid Collection, which consists of 500 books on Africa, the Negro, and sociology; and the Scott Collection, which consists of 375 general titles on black subjects. In 1968-69 the Negro Collection was greatly augmented through the purchase of the entire holdings of a local bookstore.

\section{Tuskegee Institute}

The Tuskegee Institute collections were established in the early 1900 s by bringing together materials of the older Department of Records and Research at Tuskegee, which was begun by Monroe Nathan Work and continued by Jessie Guzman. In more recent times, additional items in different collections have been assembled and acquired by the present archivist, including materials on the history of the poll tax in the South.

\section{Schomburg Collection}

Although not associated with a black college, the Schomburg Collection of the New York Public Library (the 135th Street Branch) should be recorded among the significant collections of black materials available for research. The collection is considered one of the most important centers in the world for research and study in black culture.

The Schomburg Collection has three histories, each playing a central part in its development. In the infancy of the 
New York Public Library itself, some interest was shown in collecting black materials. Materials relating to the American Colonization Society and items on slavery were collected by the library in this early period.

The Harlem community, in which the Schomburg Collection is located, is equally significant in its history. In 1905 the 135th Street Branch of the New York Public Library was established to serve a neighborhood of affluent American Jewish people. An influx of black people changed the ethnic composition of the community, so that by 1920 , it was half-black. Ernestine Rose was appointed librarian and charged with the responsibility of adapting the collection to serve an altered public.

By 1924 the Harlem Renaissance, a cultural revolution in which black writers, musicians, artists, and scholars were beginning to express their talents, was in bloom. The Renaissance leaders and their works attracted talent and leadership from black people all over the United States and the Caribbean, and they joined the 150,000 black persons who had migrated to Harlem by 1924 . Harlem was thus the acknowledged capital of black America.

The rigorous efforts of Ernestine Rose and such leaders as Arthur A. Schomburg, Louise Latimer, J. E. Bruce, James Weldon Johnson, John B. Nail, and others culminated in the founding of the new Division of Negro Literature, History, and Prints on May 8, 1925 , at the 135th Street Branch.

In 1926 the Carnegie Corporation of New York purchased the private library of Arthur A. Schomburg and presented it to the 135th Street Branch. This acquisition of between 5,000 and 6,000 volumes, 3,000 manuscripts, 2,000 etchings, and thousands of pamphlets formed the nucleus of the materials in the Division of Negro Literature, History, and Prints. Schomburg was retained as curator of the collection in
1932 through a financial gift from the Carnegie Corporation.

The Schomburg Collection, the title by which the 135th Street Branch is commonly known, now represents a reference and research library which provides various types of manuscript and archival items relating to black authorship, history and historical works, photographs, broadsides, and other materials. Papers of such notable black persons as Ira Aldridge, William Stanley Braithwaite, Alexander Crummell, Countee Cullen, Jupiter Hammon, Langston Hughes, Alain Leroy Locke, Rose McClendon, Claude McKay, Hiram Rhoades Revels, Arthur A. Schomburg, Harriet Tubman, Booker T. Washington, and Richard Wright are included in the collection.

During the years black collections in such libraries as the 135th Street Branch of the New York Public, Howard, Fisk, Yale, UCLA, and others have felt the influence of such persons as Arthur A. Schomburg, Carl Van Vechten, Langston Hughes, and Arthur Spingarn, either through materials which they presented to these libraries to enrich their collections or through the purchase of collections which they had assembled. Such persons have therefore had a marked effect on the development of notable collections of black literature.

In addition to their focus on black materials, the common element in the history of black libraries just described, including the Schomburg Collection, is the lack of proper financial support, staff, and quarters for processing and preserving the rich materials and for making them more readily available to scholars. While they have relied heavily upon gifts of notable materials to help build the collections, these libraries have been handicapped by lack of financial support required to maintain the collections. At the other extreme are the rewards that these collections can bring to scholars by the mere fact that they 
have survived in spite of undue hardships. ${ }^{4}$

\section{Administration, Organization, and Personnel}

A study of the administrative organization of black libraries housing materials in black studies indicates that twenty-seven, or 41.5 percent, of sixty-five libraries reporting have established separate collections of black studies materials, or special collections. Thirty, or 46.1 percent of the total, reported that black materials in their libraries were distributed among items in the general collection. Eight libraries failed to return this portion of the questionnaire which was used to gather data.

Patterns in administration of the special collections of black materials vary. Five of the libraries reported that their special collections departments were administered by a full-time librarian whose primary responsibility lay in that area. Seven reported that the collections were administered by a librarian with shared responsibility, devoting a part of his or her services to directing activities in special collections. The remaining collections were directly supervised by the head librarian.

Reporting on the assignment of staff members to special collections departments, findings show that thirteen libraries followed this plan, with five reporting that their services to the collection were full time. One of these assigned two professionals to the collection on a full-time basis. Ten libraries employed semiprofessional staff members in the collection, with two libraries reporting that their services were full time in the collection. The number of hours of student assistance for the collections was generally unavailable.

In each instance in which the collection was administered separately by persons other than the head librarian, such persons held the master's degree. Subprofessional and clerical persons as- signed to the collections held at least a bachelor's degree.

Thirteen libraries indicated that staff persons serving these collections continued their professional development through attendance at in-service meetings, workshops, and conferences of professional organizations. These included annual meetings of the Association for the Study of Negro Life and History (now the Association for the Study of Afro-American Life and History); an institute in the Selection, Organization, and Use of Materials by and about Negroes, held at Fisk University; conferences on the administration of archives; a conference on Materials by and about American Negroes, held at Atlanta University; institutes on archival preservation; an institute on Bibliographic Sources for a Study of the Negro, held at Howard University; and short-term conferences and institutes on more local levels. Seven libraries reported that their staffs had received additional formal education beyond their last degree.

Conferences with staff persons indicated that each of the twenty-seven libraries housing separate and special collections of black literature is seriously understaffed in these areas. Such libraries as Atlanta, Fisk, and Tuskegee, which are used heavily by researchers from various parts of the country, are especially burdened. They are required to serve increasing needs of students and faculty as well as to lend research assistance, each demanding more time than present staffs can provide. Other libraries such as Hampton, Lincoln (Pennsylvania), and Florida A\&M, which are anxious to broaden their services, are handicapped in their activities because of staffing inadequacies.

It would appear that the staff persons serving these collections, although limited in number, are well-trained and continue their education through workshops, institutes, and other activities. To 
overcome their difficulties, however, all of the libraries that have plans to improve their services will be required to increase their staffs. In reporting the staff needs for the five-year period beginning July 1, 1969, and ending June 30 , 1974, eighteen libraries indicated that they require an additional seventy persons, with most of these needs in professional positions. Only three libraries indicated that they need to add archivists to their staffs.

Written policies governing the administration and use of these collections were available in nine libraries, with the remaining fifty-six reporting that no such policies were prepared.

\section{Profiles of the Collections}

If maximum benefits are to be reaped from special collections of black materials, the collections must be organized and indexed in an appropriate manner. Where book collections are concerned, this necessarily means that an accepted scheme of classification must be adopted. In terms of classification schemes used, findings show that eleven of the twenty-seven libraries who have separate collections of black materials used the Dewey Decimal Classification for processing materials in special collections. Three libraries reported that they used the Library of Congress Classification, while ten reported that they used both LC and DDC. Three libraries had no substantial cataloging arrearages in monographic works.

Visits to the libraries showed that, where archival materials were concerned, the processing of such materials was incomplete. For the most part, these materials had been collected and were housed either in the library building or elsewhere on campus. Little had been done to index them. Collections at Hampton, Howard, Fisk, Lincoln (Pennsylvania), and Tuskegee, which included vast amounts of original research materials, were partially indexed and preserved either through microfilming or by storing them in acid-free folders and in manuscript boxes. Equally large amounts of materials were unprocessed and, consequently, unavailable for use. In addition, some of these materials were collected years ago but were unprocessed because funds were unavailable to provide staff of sufficient number and expertise to handle them.

Analysis of the scope and content of materials on black subjects housed in the traditionally black college libraries revealed that for the most part, and with the exception of the few research collections, increasing amounts of materials were gathered to support the epidemic of black studies programs. Archival materials that were in many of these collections had been housed earlier in administrative offices and recently added to the library.

Thirty-five of the institutions reported curricular programs in black studies, with degrees given in four and a minor offered in three. Fourteen offered programs in African Studies, with degrees offered in two institutions and a minor offered also in two institutions. These new emphases, or a re-emphasis on black subjects already offered in these institutions over the years, stress the need for developing strong collections of black materials to support the programs.

In general, the scope of the collections in black studies in the historically black college libraries is geared to the curricular program. Several of these libraries, most of them privately supported, have gathered other valuable research items along with their collections of books and periodicals. Such collections, therefore, serve curricular as well as research requirements in black studies.

Descriptions of the larger, richer collections (particularly manuscript materials), such as those at Hampton, Atlanta, Fisk, Lincoln (Pennsylvania), and Tuskegee, have been presented in vari- 
ous published guides. These include the National Union Catalog of Manuscript Collections, Directory of Afro-American Resources by Schatz, Guide to Manuscript Collections by Hamer, and Subject Collections by Ash. In addition to these sources, many of the black libraries have published handbooks, guides, acquisition lists, and other items which record and/or describe the contents of the collections. Examples of these are "Guide to Manuscripts and Archives in the Negro Collection of Trevor Arnett Library" and "Special Collections in the Fisk University Library."

Five of the libraries included in the survey have published book catalogs of their collections. These are Hampton, Florida A\&M, Jackson State, Lincoln (Pennsylvania), and Texas Southern. Libraries not reporting in the survey who have issued notable book catalogs are Howard and the Schomburg Collection of the New York Public Library.

Statistics of the number of volumes in black studies were available from nineteen libraries, each maintaining separate special collections. Table 1 shows that as of September 1969 there was a total of 132,578 volumes in black studies in these libraries, the largest reported at 30,000 volumes, and the smallest at 50. Collections housing sizeable amounts of black studies materials were Atlanta $(21,000)$, Fisk $(30,000)$, Hampton $(11,314)$, and Texas Southern $(18,000)$. The table shows further the percent of total library materials identified as those in black studies. It must be pointed out that certain libraries, such as those at Southern, Grambling, and Prairie View, have other black studies materials in the

TABLE 1

Volumes of Black Studies Materials in Certain Black College Libraries, September 1, 1969

\begin{tabular}{lccc}
\hline \hline \multicolumn{1}{c}{ Institutions } & $\begin{array}{c}\text { Volumes in } \\
\text { Black Studies }\end{array}$ & $\begin{array}{c}\text { Total Volumes } \\
\text { in Library }\end{array}$ & $\begin{array}{c}\text { Percent } \\
\text { in Black Studies }\end{array}$ \\
\hline pAlabama A \& M & 2,103 & 104,641 & 2.0 \\
pArkansas A M \& M & 1,700 & 59,523 & 2.8 \\
vAtlanta & 21,000 & 240,000 & 8.7 \\
vBenedict & 6,000 & 49,261 & 2.1 \\
pCentral State & 2,000 & 90,000 & 2.3 \\
pCheyney & 2,000 & 86,760 & 1.9 \\
vClaflin & 767 & 38,385 & 18.3 \\
vFisk & 30,000 & 163,467 & 4.7 \\
vFlorida Memorial & 2,000 & 41,862 & 9.3 \\
pGrambling & 1,250 & 80,754 & 2.3 \\
vHampton Institute & 11,314 & 120,616 & 7.3 \\
vJarvis Christian & 910 & 38,522 & 5.5 \\
pKentucky State & 4,305 & 58,806 & 5.8 \\
pLangston & 1,714 & 108,218 & 5.6 \\
vLeMoyne-Owen & 3,000 & 50,586 & 9.0 \\
vLincoln (Pennsylvania) & 6,893 & 117,612 & 7.9 \\
vLivingstone & 2,476 & 44,156 & 1.4 \\
vMorris & 1,900 & 21,025 & 8.1 \\
vPaul Quinn & 2,000 & 25,150 & 2.3 \\
pPrairie View & 1,696 & 116,358 & 10.0 \\
vSt. Augustine & 4,000 & 49,009 & 3.8 \\
pSouthern University & 700 & 212,435 & 13.68 \\
vStillman & 850 & 39,121 & \\
pTexas Southern & 18,000 & 179,866 & 102,891 \\
vXavier & 4,000 & $2,239,024$ & \\
\multicolumn{1}{c}{ Total } & 132,578 & & \\
\hline
\end{tabular}


general collection that were not reported.

Materials in forms other than books, periodicals, and newspapers were found in a number of these libraries, particularly in the special collections of black materials. Types of materials reported in the various libraries are shown in Table 2 . As the table indicates, slightly

\section{TABLE 2}

Types of Black Studes Materials Held by Libraries in Certain Traditionally Black Colleges, September 1969

\begin{tabular}{lr}
\hline \hline \multicolumn{1}{c}{ Types of Materials } & $\begin{array}{c}\text { Libraries } \\
\text { Reporting }(\mathrm{N}=65)\end{array}$ \\
\hline Manuscripts & 10 \\
Microfilm & 23 \\
Microfiche & 0 \\
Microcard & 20 \\
Microprint & 21 \\
Recordings & 14 \\
Tapes (audio) & 4 \\
Tapes (video) & 9 \\
College archives & 35 \\
Other archives & 6 \\
Films & 6 \\
Filmstrips & 16 \\
Reproductions & 4 \\
Photographs & 17 \\
Slides & 7 \\
Scrapbooks & 14 \\
Uncataloged pamphlets & 18 \\
Art objects & 8 \\
Paintings & 9 \\
\hline
\end{tabular}

more than one-third of the libraries included in the survey reported no holdings in black studies materials in the form of microfilm, Microcard, and Microprint. Thirty-five libraries reported that college archives are collected. Other types of materials are generally less well represented in these collections.

Special gifts of materials that have been added to these libraries during the past five years include a number of manuscript collections in such libraries as Atlanta, Hampton, Fisk, Lincoln (Pennsylvania), Tuskegee, Virginia State, Kentucky State, and Livingstone. Some of these collections also include books. In 1969 the Southern Association of Colleges and Schools presented col- lections of paperback books in black studies to each of the black college libraries. The purpose of the gift was to enrich holdings in this area and to make the materials easily accessible to students, particularly in libraries where few materials of this type had been collected. An examination of the collections in these libraries revealed that these materials greatly enriched black studies materials already gathered, frequently forming the nucleus of newer collections in that area.

Of particular significance to those colleges who were members of the United Negro College Fund in 1969, the 3M Company helped to supplement and to enrich their special collections and general materials on black studies by presenting a collection of materials on microfilm as well as two reader-printers for their use. The collection consisted primarily of black studies materials filmed in the Schomburg Collection of the New York Public Library and was designed for use in curriculum enrichment.

Frequently, the development of collections along desirable lines is more easily assured when acquisition policy statements are prepared and observed. Ten libraries reported that such policies had been developed for collecting black materials, with eight of these reported in libraries where separate special black collections were established.

Materials used for book selection in these libraries generally included such sources as Bibliographic Survey, Ebony, Black World, Journal of Negro History, Negro History Bulletin, Publishers' Weekly, Choice, Freedomways, Bibliography of the Negro in Africa and America, and catalogs of various reprint companies. Atlanta and Fisk reported use of Library of Congress catalog cards, which have been sent to them continuously over the years expressly for the purpose of selection in this area. A few libraries used the Dictionary Cata- 
log of the Schomburg Collection of Negro Literature and History for building collections.

Responsibility for selection of materials was generally placed with the library staff, with the faculty assuming much less responsibility in this area. In some instances, however, the faculty and the library staff shared this responsibility.

The physical condition of materials on black subjects in these libraries was generally good. Four reported that the materials were in fair condition, while two reported that their condition was poor. Some of the manuscript and archival materials in the larger research collections were brittle and fragile, as they succumbed to extreme conditions of heat, humidity, and dust over the years, at times before they were acquired by the library and at other times after they were collected.

\section{Facilities, Services, and Programs}

Standards of the American Library Association suggest that the success of a library's services is presupposed by an adequate library building, with ample quarters for processing and similar activities. Ideally, services which the library undertakes must be provided for in areas that are well-planned. These standards are immediately applicable when special collections are provided. Buildings must take into consideration the functions that special collections are to serve, particularly when these functions involve service to the students and faculty as well as research functions, as is the case with several of the black colleges.

In studying facilities for housing and servicing special black collections in the twenty-six libraries reporting, it was found that quarters in three libraries were excellent, those in fourteen were good, those in four were fair, and those in four were poor. Two responses were not given. Nineteen of the libraries re- ported that quarters for special collections were air-conditioned. The condition of furniture in these libraries ranged from excellent to poor and was about evenly divided in the various categories.

Size of quarters varied. Two libraries had exceeded their capacity; another, a new facility, had already reached its capacity; while ten had room for expanding the collection. For the most part, seating was provided at tables in special collections areas, with few provisions made for individual as well as informal seating.

Access to stack areas housing these materials was provided for undergraduate students in seventeen libraries, with ten reporting that stacks were closed. Graduate students were provided direct access to stacks housing black studies materials in seven libraries, although some of the reporting libraries had no graduate students. Faculty access to the stacks was provided in seventeen libraries. Eight libraries reported that stacks were closed to all patrons.

As in libraries generally, loss of materials through theft was a common problem. Frequently, such losses reached serious proportions and deprived students and faculties of items needed almost daily for class work. Popular and classic works such as Soul on Ice, The Negro in American Culture, and From Slavery to Freedom were nearly always lost. New materials placed on the shelves frequently disappeared immediately when they met the current interests of patrons.

Equipment available in the special collections areas generally included microfilm readers, microfilm readerprinters, record players, filmstrip projectors, and slide projectors.

Hours of service varied from a high of ninety per week to a low of fortyfour. Service at night was provided in twenty libraries, with the highest number of night hours reported at twenty- 


\section{4 / College d Research Libraries • September 1974}

nine, and the lowest at four. Sunday hours were provided in nineteen libraries, with a high of eight hours provided in one library as compared with a low of three in another.

Statistics on use of the collections, including interlibrary loan, were generally unavailable, as many libraries counted use of the collections with those of the general circulating collection. Materials in the majority of these libraries were available for use outside the library, with twelve libraries reporting that materials were restricted to room use only.

Thirty-one libraries reported that they provided special services, such as preparation of bibliographies. Common practices among the libraries were assistance to faculty, students, and members of the community in compiling bibliographies; presenting special book reviews, lectures, and other activities during Negro History Week; and generally lending assistance as needed. $\mathrm{Li}$ braries housing sizeable amounts of original research materials reported that they provided research assistance to visiting scholars and assisted in the use of these materials.

Of those collections housed separately, six libraries reported that they contributed to union lists of materials; nine participated in cooperative acquisition programs with other libraries in the region, while seven were involved in special agreements concerning use of materials with other libraries. Of those libraries incorporating black materials in the general collection, six were engaged in consortia activities which involved the collection and/or use of black materials.

Plans for automating various activities in special collections were reported under consideration in three libraries. These included information retrieval and preparation of bibliographies.

\section{Financial Aspects}

As is true with general library collec- tions, adequate financial support must be provided to permit proper development of the collection. When special collections are provided, it follows that increased budgets will be needed to support the development of services for which these collections are maintained. Special collections may require additional staff persons, depending on the administrative organization of this part of the library.

Separate budgets for the support of special collections were generally not provided in the libraries reporting. In only two instances were separate budgets established. Libraries indicated that funds from the regular library budgets were used for this purpose.

In attempting to determine whether or not special financial grants had been provided to support these collections during the years 1964-65 through 196869 , it was found that six libraries received a total of $\$ 83,961$ during the years in question. Grants varied from a high of $\$ 32,000$ to a low of $\$ 1,200$. None of the collections was endowed. A full appraisal of the expenditures for library materials in black studies in the reporting institutions, including grants and gifts as well as funds from the general library budget, cannot be made.

Expenditures for materials in black studies were generally made by the library staff, with a few instances of allocations to departments. Such departmental allocations were made in connection with total library development, rather than with a view toward exclusive development of special collections. Proper development of the collections was attempted by strengthening weak areas as well as by gearing selection practices to fit the needs of the curricular and research programs.

\section{Projections for the Future}

Libraries were asked to report any special problems they faced which af- 
fected the development or use of their special collections. Responses may be summed up in terms of spatial and financial needs, as many of the quarters were crowded, with little provision for staff work space. A number of the libraries were understaffed, particularly in terms of librarians with expertise needed to administer the collections. All libraries reported inadequacies in the financial support received, asserting that their unfilled needs were the primary reasons behind their problems.

Projections for the future included strengthening and greatly expanding the book collections, gathering college archives, expanding collection practices to gather other materials in the region, enlarging quarters, moving into new quarters, adding new staff, and developing black oral history programs.

\section{SUMMARY OF FINDINGS}

The development of collections of black literature in the traditionally black college libraries showed varying patterns, with some libraries reporting the inclusion of such materials in their libraries from the year of inception and others reporting the establishment of collections in later years by interested benefactors. Still others, in more recent years, established these collections to support the epidemic of curricular programs in black studies or, in some instances, as a response to the demands of students protesting the absence of such materials in forms more visible to them.
The exceptional libraries found in the black colleges are those that have developed rich collections in black studies materials. Although they may be lacking in other areas, the libraries in which these collections are found have become notable. Even with this achievement, the libraries have not been without problems of underfinancing, cramped quarters, and insufficient staffs to process materials and to serve the needs of students, faculty, and scholars who use the collections.

Collections of black literature now found in the traditionally black libraries serve one or more purposes, depending on the nature of the resources. Some may be geared to serve only the instructional program of the institution; some serve the curricular needs as well as the research requirements of scholars; and, in almost every instance, each responds to the requirements of the community by providing resources in this area. If these needs are to be met, and if these libraries are to continue to function in their traditional roles simultaneously, they will require additional and substantial financial support.

The history of black people, black colleges, and black libraries supports the conclusion that the black heritage must be preserved. Black students, and others, must be introduced to this heritage more completely through larger, richer collections of black literature. The traditionally black colleges and their libraries share this responsibility.

\section{REFERENCES}

1. Earl J. McGrath, The Predominantly Negro Colleges and Universities in Transition (New York: Bureau of Publications, Teachers College, Columbia University, 1965), p.129.

2. U.S. Office of Education, Federal Security Agency, National Survey of the Higher Education of Negroes, Vol. 1, Misc. No. 6
(Washington, D.C., 1942), p.98.

3. Wallace Van Jackson, "The Countee Cullen Memorial Collection at Atlanta University," The Crisis 54:140-42 (May 1947).

4. Arna Bontemps, "Special Collections of Negroana," Library Quarterly 14:187-206 (July 1964). 